DIGITAL COMMONS
@ UNIVERSITY OF SOUTH FLORIDA

Volume 10

Issue 1 Spring 2020

\section{ABO: Interactive Journal for \\ Women in the Arts, 1640-1830}

\title{
Entering the Lady's Dressing Room: Using feminist game design to look at and beyond the male gaze in Swift's The Lady's Dressing Room.
}

Melanie D. Holm

Indiana University of Pennsylvania, holm.melanie@gmail.com

Follow this and additional works at: https://digitalcommons.usf.edu/abo

Part of the Digital Humanities Commons, Educational Methods Commons, Feminist, Gender, and Sexuality Studies Commons, and the Literature in English, British Isles Commons

\section{Recommended Citation}

Holm, Melanie D. (2020) "Entering the Lady's Dressing Room: Using feminist game design to look at and beyond the male gaze in Swift's The Lady's Dressing Room.," ABO: Interactive Journal for Women in the Arts, 1640-1830: Vol.10: Iss.1, Article 2.

http://doi.org/10.5038/2157-7129.10.1.1193

Available at: https://digitalcommons.usf.edu/abo/vol10/iss1/2

This Digital Humanities is brought to you for free and open access by Digital Commons @ University of South Florida. It has been accepted for inclusion in ABO: Interactive Journal for Women in the Arts, $1640-1830$ by an authorized administrator of Digital Commons @ University of South Florida. For more information, please contact digitalcommons@usf.edu. 


\title{
Entering the Lady's Dressing Room: Using feminist game design to look at and beyond the male gaze in Swift's The Lady's Dressing Room.
}

\begin{abstract}
In 2017, I developed "Entering the Lady's Dressing Room," an Interactive Fiction game based on Jonathan Swift's satiric poem "The Lady's Dressing Room" (1734) to help my students become better readers of Restoration satire, and poetry generally. I did this for two reasons: to test whether the digital mediation of game-playing could help my undergraduate students more fruitfully engage with the poem, and 2) to theorize the similarities between poetic interpretation, the multiple narrative-making experience of gameplaying. This article takes seriously the idea that poetry is play. It describes the circumstances that led to the development of the game and why Swift's poem seemed an appropriate site for such experimentation. Crucial to game construction is a commitment to theories feminist game design that complement the poem's own indictment of sexist determinism. With meditations on the affinity between poems and games, an examination of preceding experiments of literary translation into the ludic digital, details on game construction and local objectives, this article reflects on how digital mediation suggests a self-conscious mode of reading as a phenomenon of fictional world building. I don't mean to suggest that this approach is necessarily appropriate for every poem or that every poem can be translated into the digital sphere in this way; rather, I want to share how the case of Entering the Lady's Dressing Room suggests that the experience of translating a poem into Interactive Fiction can contribute to the formation of careful, detail-oriented reading practices in undergraduate readers. And poetry, if nothing else, is about the details.
\end{abstract}

\section{Keywords}

Interactive Fiction, Digital Pedagogy, Jonathan Swift, Feminist Pedagogy, Restoration Satire, Poetry

pedagogy, restoration poetry, feminist game design

\section{Creative Commons License}

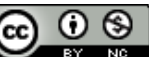

This work is licensed under a Creative Commons Attribution-Noncommercial 4.0 License 
If you were in the place of Strephon from Jonathan Swift's 1732 poem "The Lady's Dressing Room," what would you do once Celia "from her chamber issues, I Arrayed in lace, brocades and tissues" (1. 2-3)? Would you walk up to her to say hello, or would you steal inside once she had left? This decision is the first of many for players of Entering the Lady's Dressing Room, a digital interactive fiction game that I designed as a learning resource for students and other readers of Swift's mock-heroic poem. The game reframes the poem as a series of individual decisions that place responsibility for interpreting objects and encounters from the poem on the player, as well as the responsibility for acting on those interpretations. Asking students to make narrative choices mandates pauses in reading that create alternative and comparative spaces of consideration in which student can engage the feminist, cultural, and epistemological concerns of and surrounding Swift's poem. This process enhances close-reading skills by displacing the text into an experiential paradigm structured on feminist pedagogical principles-subjectivity, distributed authority, experience, and multiplicity 1 - enacting an ironic corrective to the dogmatic, hegemonic, and sexist beliefs that Swift's work has been understood to both promote and indict (Cassell 304). ${ }^{2}$

The Dressing Room was developed in response to a shared experience of students misreading or under-reading the poem. Ellen Pollak's description of teaching the poem in 1992 provides a typical classroom tableau:

The initial response of students is often quite predictable: that the texts express a disgusted view of the female body and a high degree of violence against it.

More confident students will insist that the poems clearly expose Swift as an unreconstructed misogynist and will point effectively to any number of passages to support their view ("Swift" 117)

Pollak's description matched my own experiences of teaching Swift's poem to undergraduates. One reason I found that they replicated the predictable response is that my students, and likely others, tend to read the poem passively. They follow its narrative progress through either the positions of Strephon or the speaker and accept rather than analyze points of view or develop one of their own. Participating in a digital space in which they must actively and self-consciously choose whether to engage with Celia or to scrutinize her things and her as a thing, by contrast, asks the student-players to interact with the poem in a dynamic way that dramatizes the roles of choice, judgment, and methods of judgment and engages the poem on multiple satirical levels. As a result, they make their own decisions about the status of a particular woman in the poem, "Celia," and of women as a category in the 
poem's symbolic, intertextual, and empirical frameworks, as well as the patriarchal structures of seeing and judging that the poem clusters around its absent female center. This psychologically embodied engagement enacts practices of feminist theory: students enter into Swift's poetic world in a manner that encourages their multiple subjective views and revisable responses. Players consider the voices, objects, and events of the poem through the gaze of a male protagonist; however, they are distanced from and made conscious of its constraints, enabling the production of independent, evidence-based readings drawn from their complex and nuanced experiences. The go through the game as Strephon, but what Strephon does - what he thinks and how he acts - is up to them, yielding a variety of possible ways to navigate the world of The Dressing Room-some that reproduce the misogyny of eighteenth century and some that repudiate, and some that fall somewhere in between. The goal of the game is not to convince students that the poem is or is not a feminist work, but to use feminist game design to change how students interact with the poem. By slowing them down, multiplying perspectives, and creating choices, the game intends to help them arrive at their own conclusions in successive rereadings of the poem.

Readers of $A B O$ will likely be familiar with "The Lady's Dressing Room" and the controversies surrounding the indirect depiction of its heroine Celia, as well as the conclusions of its speaker and antihero on the nature of women. As a parody of the figurative overreaching of the Petrarchan blazon, Swift's poem deconstructs the poetic ideal of an always already constructed woman made up of perfect parts. In so doing, Swift deflates the aristocratic ideal of woman as supranatural, ridiculing naïve belief by unmasking the physicality of embodied female humans. What women's bodies and women-as-embodied mean in the poem, as well as what meaning can be gleaned by the accumulation of physical evidence by imperfect, limited human understanding, are questions that facilitate the more complex satiric jousts of the poem. As Tita Chico has argued, rendering Celia an object of empirical inquiry renders empirical methods and meaning-making objects of ridicule every bit as much as Celia and the objects in her. ${ }^{3}$ At the same time, her objects are alternatively linked in a complex synecdoche to the problems of global trade and market capitalism and intertextually to poems such as Pope's Rape of the Lock (1712) that comically depict women drawing resources from around the world to better market themselves visually. ${ }^{4}$ With an emphasis on the visual, readers vicariously watch and are implicated in envisioning Celia (as well as Strephon) as an object to be looked at and, through that look, defined and evaluated.

Part of what is at stake in this poem, then, is the status of the look, or, in Laura Mulvey's well-known cinematographic term, "the male-gaze," along with its ideological and power assumptions. As Mulvey defines it, the male gaze is made 
up of three looks: (1) the man behind the camera; (2) that of the male characters within the fictional world of film; (3) that of the spectator or audience of the film who gazes at the image on the screen (843). These looks bear a striking resemblance to the different specular levels of Swift's poem: (1) Strephon; (2) the speaker; (3) the poem/reader. The status of the empirical — if not male - gaze is a site of satire and debate in the poem and in readings of the poem. One way in which instructors can encourage readers to examine this aspect is to allow them as game-players to interact with the poem as game-players, conscious of the constraints of that gaze, while activating a space for the potentially multiple perspectives and speculations of a "female gaze." According to Lorraine Gamman, the female gaze is not merely an inversion of the male gaze in which women sexualize or objectify men but a displacement of the hegemonic power of a singular way of looking that creates and values the possibility of multiple viewing angles: "The female gaze cohabits the space occupied by men, rather than being entirely divorced from it" (16). It does not appropriate or claim its voyeuristic privilege but calls into question and disrupts its presumption of privilege and power by empowering, acknowledging, and valuing alternatives. Chico argues that the poem satirizes the lack of possible alternatives in the empirical scientific/male gaze in its assumption of "transparent signifiers" that have stable meanings (145). Though they disagree in their readings, for Strephon and the speaker, there is but one way of seeing things and, in turn, one way of contextualizing or reacting to what one sees. If, as Swift argues, "Satire is a sort of glass, wherein beholders do generally discover everybody's face but their own," then the disruption of the gaze allows players both to see themselves and see for themselves (Tale of a Tub 141-42).

Framed by a collaboration of the principles of feminist pedagogy and feminist game design, The Dressing Room invites the student player to interact with Celia and the objects in her dressing room through a series of independent choices. ${ }^{5}$ They "see" the object and are allowed through the multiple paths offered by interactive fiction to develop their point of view, and from there, choose what they want to see next. Feminist pedagogy for Swift's poem has mainly focused on exposing students to a variety of feminist criticism as a way of opening up and generating conversation. For example, Pollak writes:

Whether or not one chooses to expose every class to the full range of criticism at first hand, there seems to me no better way to acquaint students with the issues at stake in a feminist analysis of Swift than by reproducing the divergent lines of inquiry that feminists have pursued in approaching the representations of women in his work. (117) 
Proposing that students engage the poem through gameplay is not meant to suggest a better way to expose students to the issues at stake in feminist analysis. It is a complementary technique drawn from feminist game design and pedagogy that is especially suitable for students in a survey or general education class who struggle with reading poetry and its criticism.

Computer scientist and human-technology interaction theorist Justine Cassell has argued for the parallels of feminist pedagogy and game design in the following ways. Feminist pedagogy, she explains, "transfer[s] authority to the student"; "value[s] subjective and experiential knowledge"; "allow[s] a multiplicity of viewpoints"; "give[s] the student voice to express the truth of her life as she experiences it"; and "encourage[s] collaboration" (304). Similarly, feminist software design "transfer[s] design authority to the user; value[s] subjective and experiential knowledge in the context of computer use; allow[s] use by many different kinds of users in different contexts; gives the user a tool to express her voice and the truth of her existence; encourage[s] collaboration among users" (30405). Employing these tenets of feminist game design and feminist pedagogy, The Dressing Room creates a space for different potential responses to the objects of the poem. It thereby enables user agency by allowing for choice. It encourages players to cultivate their own relationship with Celia by challenging the methods by which Strephon and the poem's speaker reach their misogynistic conclusions and possibly, those conclusions themselves. With anywhere from two to five choices at each stage of The Dressing Room, the game design privileges subjective experience by enabling seventeen different outcomes (alternative endings) with myriad internal paths - only one of which reproduces the psychological and narrative drama of Swift's protagonist. ${ }^{6}$ The game articulates through individual experience in digital space a variety of possible experiences, and as a result, the instability of interpretations and alternative associations of ideas that the poem itself can only articulate through comic omission.

As a feminist pedagogical and digital tool, the game provides a supplement for students to explore dimensions of the poem outside of the context of a lecture or class discussion. It is a venue in which they can slow down and interact with poetic elements outside of their narrative embedding, and thereby return to the poem with eyes that belong neither to Strephon nor the speaker. The game space also offers the advantages of using digital technologies to incorporate bibliographical, allusive, and cultural content that enlarge possibilities for textual experiences and increase awareness of the poem's complexities. James Paul Gee's thinking about games as useful in scientific education is therefore transferable here to the realm of the literary: "They situate meaning in a multimodal space through embodied 
experiences to solve problems and reflect on the intricacies of the design of imagined worlds and the design of both real and imagined social relationships and identities in the modern world" (48). The essay that follows will consider the digitally-mediated embodiment of this poem by addressing (1) the philosophical and aesthetic concerns surrounding making a game from a poem and thinking of a poem as a game for the pedagogical purpose of teaching Augustan satire; (2) literary game history and culture; (3) the game's technical architecture; (4) student work and outcomes from two different classroom environments alongside thoughts for revision and possible applications. Rather than argue for a particular reading of the poem, this article describes a feminist approach for using digital technology to facilitate multiple student readings of the poem - its objects, protagonists, satires, and gender politics - with increasing levels of sophistication and reflection through repeated play.

\section{Game as poem/poem as game}

The conceit of poem as game is common among major language and poetry theorists of the twentieth century and at least as old as Horace, whose poetic reflection on words, Haec ego ludo (I play with these things) characterizes poetic construction as a game and words its objects of play. ${ }^{7}$ Margaret Doody further notes that Horace "is playing a game of genre and styles" (92):

No poem seems fixed by any regulations which demand the maintenance of one particular style or tone, and the reader cannot be sure how the poem is to end, or how the beginning and ending will be related, or how many various genres will be taken up and sliced and popped into the stew. (93)

Horace plays with his reader through his intricate play with poetic language and convention. His multilayered gamesmanship, Doody argues, was critically influential to the Augustan poets, Swift among them: "The Horace of the sermones has the qualities which the English poets of the late seventeenth century and the eighteenth century valued. . . He capitalized on generic instability, created new genres, mixed styles" (95). Swift is well-known for his parodies of genres and styles in the Horatian (as well as more extreme Juvenalian) mode. His achievements are due in part from his celebration of what Clive Probyn has called "ludic writing (puns, acrostics, riddles, grotesque rhymes, tortured syntax) - all means of keeping the linguistic surface in front of the reader, and of keeping all claims to absolute truth and reality at bay" (285), as well as what Derek Mahon calls a "ludic taste for popular forms and idioms" and a "vernacular zest" (802). As Simon Alderson notes, "Swift refers to his friend Charles Darteneuf as "the greatest punner of this town 
next myself,' indicating that punning in the town had its own hierarchies, its own reputations, its own social codes and outlets" even as it worked against the middleclass antipun attempts at social hierarchy and control" (9). ${ }^{8}$ Playful punning, as Swift practiced it, was thus both a social-cultural argument as well as a "diversionary language game" (16). Such language and genre play are crucial for the larger game of moral satire Swift plays with his readers as well as the amusements of reading the text.

Swift is exemplary for demonstrating the fundamental role of play in poetry. The ludic posture and playfulness of poetic language are intrinsic to his poetry's gamesmanship. "The poet's position is analogous to that of someone who is designing a game, while the reader's position is analogous to that of someone who is playing or watching the game," as John Redmond notes (9). Deploying this metaphor in an instructional context, Reuben Brower has argued in his influential literary-pedagogy essay "Reading in Slow Motion" that reading is and ought to be an actively amusing game. Distinct from "reading as a pursuit of fact or useful technical know how" (3) is

reading as active amusement, a game demanding the highest alertness and the finest degree of sensibility, "judgment ever awake and steady self-possession with enthusiasm and feeling profound or vehement." . . I say "amusement," not "pleasure," to stress the play of the mind, the play of the whole being, that reading of this sort calls for. (3-4)

My assumption in creating The Dressing Room is that turning a poem into a digital rather than metaphorical game requires activating the play of the mind Brower describes by making the reader into a self-conscious player who "enter[s] into" the poem as a virtual space.

The playfulness of Swift's poem is not necessarily readily apparent to students on their first reading, nor do students readily come to the poem with a mind that is ready to play. Restoration poetry, particularly satire, poses two significant barriers to entry for beginning student readers that discourage the curiosity requisite for asking questions about the gender provocations and epistemological incursions in Swift's work: (1) the complexity of Restoration poetry and (2) the reading practices of contemporary students. Frederic Bogel suggests students feel a high degree of "discomfort" when reading Restoration satire, which derives from the intricacies and density of its language and its high degree of literary and historical allusions (43). Plentiful and obscure, allusions create a "need for frequent annotation" that causes students to repeatedly move from "text to footnote" with the result that "the 
student may come to feel that he or she has been led into a ritual display of ignorance, and that the text has maneuvered its readers into a position uncomfortably like that occupied by the figures it satirizes: a position of duncical incompetence" (43-44). The typical student tendency to approach poems as sets of discrete information compounds barriers of language, history, and allusion. Many students read by vertically scanning texts for a clear statement of what they are about. If a student approaches Swift's poem in haste scanning for key terms, they will quickly become overwhelmed by the army of vulgar objects that march through the trochaic lines and promptly surrender. For sophisticated readers equipped with the formalist conviction that satire is a formula of satirist and satiric object, the most expeditious and obvious solution to the question "What is it about?" is to bestow a conflation of speaker and Strephon with satiric authority, with Celia as the representative female satiric object. This scavenger-hunt approach relieves students from burdens of form and symbolism, asking them only to find what they believe they should be seeking in the first place.

Students' pursuit of answers to the formula $x$ satirized $y$ for reason $z$ hazards a secondary readerly disaffection. Focusing too intensively on what Allan Ingram designates as Restoration satire's "act[s] of exclusion" (51) - the satiric judgments that use laughter to dehumanize and demonize its object - can trigger resistance toward a perceived fetishizing of authority. ${ }^{9}$ Bogel further argues that "our students tell us in numerous ways that they are made uneasy by the spectacle of the satirist sitting in judgment on a wide range of real and imagined poetic or moral failures. . .. [I]t is this act of judgment that chills the sympathetic current of the undergraduate soul" (44). The satire thus becomes as repugnant as the foul content it unmasks. Students are thereby likely made uncomfortable, on the one hand, by a perceived mockery of their ignorance and, on the other, by a reticence to laugh derisively at others, with both possibilities contributing to misreading enhanced by too hasty, information-seeking reading practices.

One way a digital game begins to address these issues is to reposition and redisposition student readers by turning them into players rather than informationseekers, giving them the tools to participate in the sophisticated and playful fictional world of Swift's satire. By displacing the fictional world of the poem into the digital, words are made objects and actions with which students can playfully experiment. Through this play, they begin to uncover the terms and movements of the text within its historical and literary contexts while contemplating the views expressed within the poem but not endorsing them. Making a game that is accessible by various screens seems an appropriate choice for creating an environment in which students would feel free to play because they are already comfortable displacing large sections of their lived experience into the digital 
world. The game's digital displacement then emplaces them, through their reactions and judgments, in the psychological drama of the text so that they, too, may look into the glass of satire without feeling judgmental and judged or participating in an economy of right or wrong.

\section{Digital literary games}

Adapting literary texts to a space of digital play is not a new phenomenon. As early as pre-internet 1984, Windham Classics released computer-games based on canonical children's literature that were hybrids of interactive fiction and pointand-click adventure games. ${ }^{10}$ Playing these games required knowledge of plot and details from the books to progress from stage to stage and allowed children to redeploy the actions of, for example, Alice of Alice in Wonderland, and relive her movements and decisions throughout the novel's fantasy world in an alert, playful way. In so doing, these games were deemed "educational" (Brown, Taking Advantage 124) because they "sharpen[ed] understanding of what it takes to make a story" (125) and helped encouraged students to "make decisions 'in character,", which requires "taking into account specific fictional conditions" of the novel's world.

Our digital age's development of literature-based games predominately clusters around the plays of William Shakespeare and the novels of Jane Austen, with various degrees of educational intent. Gina Bloom has designated three game genres drawn from Shakespeareana applicable to the broader world of literary games: scholar-making games that test factual knowledge and trivia; dramamaking games that allow the player to take on the role of a character; and theatermaking games, such as Play the Knave (2016), that give players the chance to play at producing one of his plays through its various stages (115). Digital Austen games largely and most successfully tend toward recreating an experience of her Regency world in the drama-making vein for entertainment and information dissemination, usually as playful extensions of the marriage plot. ${ }^{11}$ At the same time, they assist readers in developing useful frames of reference for thinking through Austen's fictional worlds with contextual historical information. Similarly, Shakespearean theater-making games extend our experience with the text through dramatic enactment rather than ask us to explore the exegetical methodologies we bring to texts. However, the experience of producing a virtual play augments the understanding of the drama's material complexity and plasticity. A further innovative digital game form is modeled by Elegy for a Dead World (2014), which asks readers to explore a solar system populated by planets inspired by three British Romantic poets. This game engages with poetic language and modes to develop the landscape of each world with some identification 
activities. Its primary goal is the production of fiction writing through real-time journaling of player experiences in-character during play, although reader interest is often developed for the poems and poets. As these examples illustrate, a variety of literary games exist with a complementary variety of teaching objectives and user outcomes, but they are not complementary variety of teaching objectives and user outcomes, but they are not designed to complicate our consumption of poetic language or literary devices. The Dressing Room modestly (particularly by the production standards of many digital enterprises) aims at these objectives by staging close-reading through encounters with objects and narrative instability within a fanciful, and reductive Restoration cultural space that players may explore as their own narratives unfold.

\section{Game architecture}

The Dressing Room makes use of the possibilities offered by interactive fiction to choose among different narrative threads in a limited virtual space so that the player assumes the position of the poem's protagonist, Strephon, but not his character. It is designed to be played by readers of Swift's poem in an at home or in a classroom environment (face-to-face or virtual) with the end goal of helping students become better engaged with the poem and the feminist concerns surrounding it. Formally, the category of interactive fiction games represents a collection of characteristics described by Nick Montfort as "a text-accepting, text-generating computer program; a potential narrative, that is, a system that produces narrative during interaction; a simulation of an environment or world; and a structure of rules within which an outcome is sought, also known as a game" ("Toward a Theory" 26-27). By asking players to make their ways into, through, and out of the dressing room, The Dressing Room enables them to discover the satiric mediation and representational rules that govern the fictional world of Swift's poem for themselves through a playful array of outcomes.

When students begin to play The Dressing Room, they are presented with a screen that gives them their character identity, their context, immediate surroundings, and options for what to do next (See figure 1). 
Your Name is Strephon and the year is 1732 . You are madly in love with Celia, a young woman of quality whose beauty, like all of Swift's pastoral heroines, seems to transcend mere human materiality-

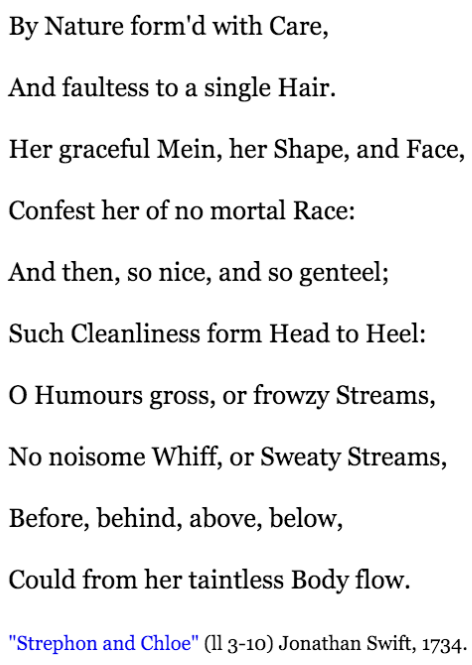

After five hours lurking outside of her door, you see Celia leave her dressing room. Do you:

Run up to her and ask her to join you at a chocolate shop?

or

Hide and wait until the coast is clear to sneak into her room while she is gone?

\section{Figure 1: Start Screen for The Dressing Room}

In this way, the game self-consciously mimics one of the original interactive fiction games, Zork: The Great Underground Empire - Part I (1981) (see figure 2) while also taking advantage of improved point-and-click technology and hyperlinking. 


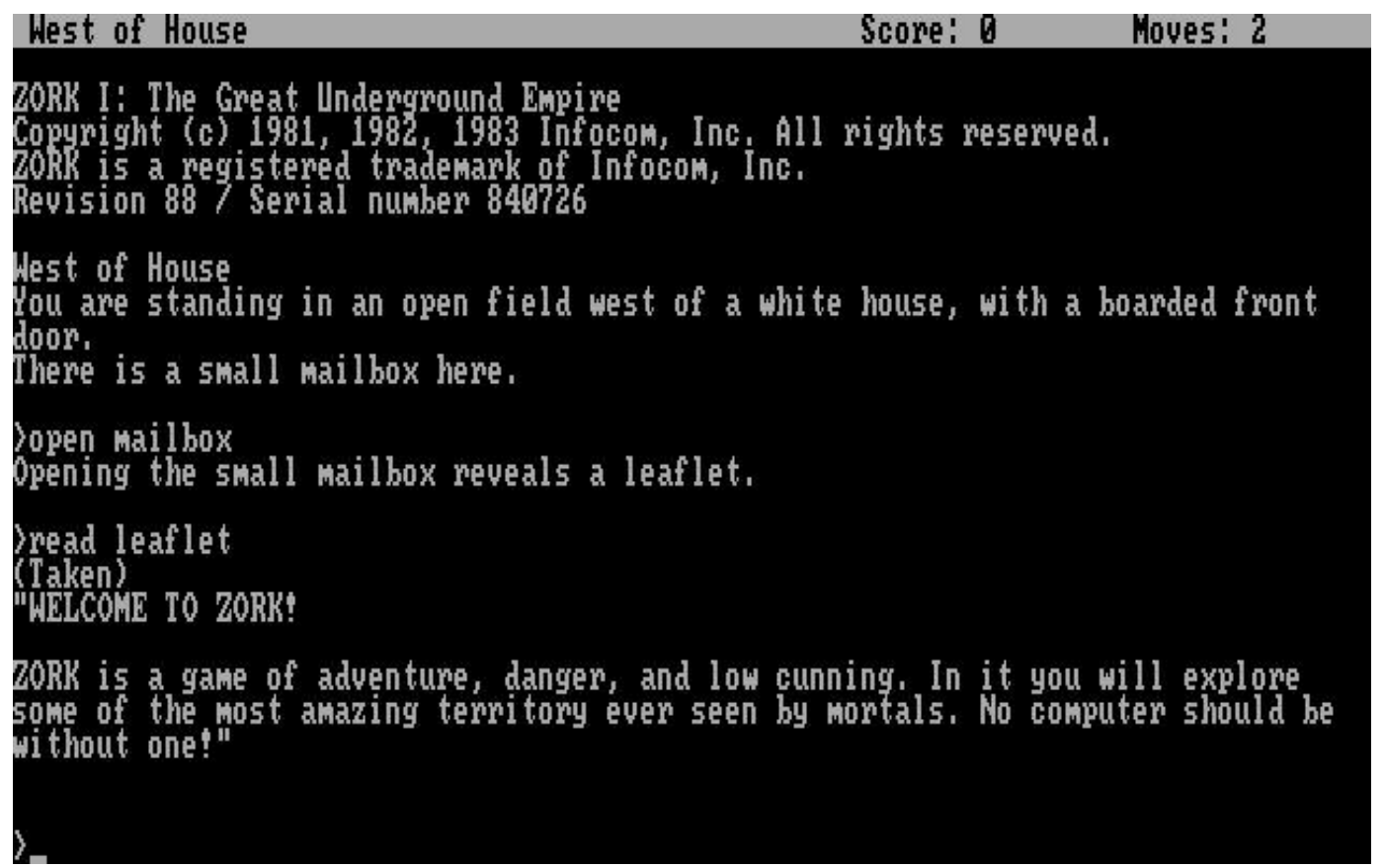

\section{Figure 2: Start Screen for Zork}

An "interactive fiction" and "fantasy story," Zork allows players to explore a series of linked spaces in a fictional world in which they encounter non-player characters and objects about whom they make action-oriented decisions. The Dressing Room draws inspiration from this spartan display in order to keep players focused on textreading and narrative production, deviating with occasional images for clarification of terms and hyperlinks acting in lieu of literary footnotes. In figure 3, for example, the link "Francis Bacon" opens the relevant passage from The Advancement of Learning in a new window so that students can further pursue the Enlightenment correlation between the desire for knowledge with the desire for power over (a usually feminized) something. 


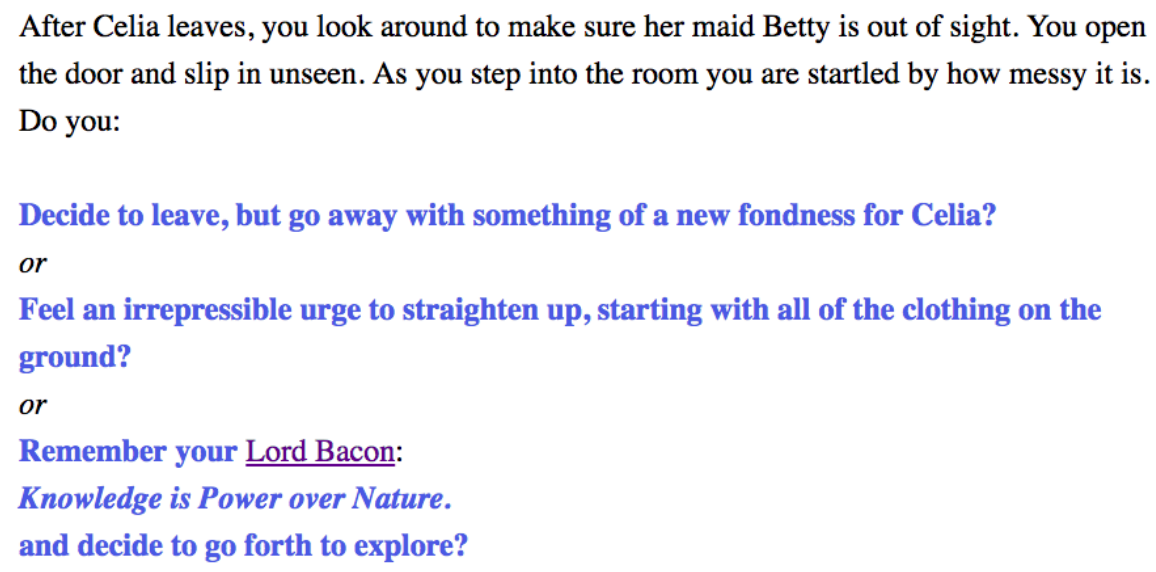

Figure 3: Typical object encounter screen.

The dynamic narrative potential of interactive fiction offers a way for students to interact with the poem dialogically as self-conscious readers and authors of alternatives. The game deconstructs the poem into a series of decisions made within a virtual space about people and objects that empowers the player to do things differently, changing not just the narrative and outcome but also the relational meaning of the poem's elements to the protagonist's progress. Separating playercharacter from poem-protagonist denaturalizes actions and conclusions within the poem, rendering them not inevitable but the outcome of a particular series of biased and causal decisions. For example, the game opens by problematizing the protagonist's first action in the poem: "Strephon, who found the Room was void, I And Betty otherwise employ'd; / Stole in" (Swift, "Lady's Dressing Room" 11. 57). The parallel moment of the game narrative presents the player with a choice that goes unacknowledged as a choice in the poem (see figure 1).

Do you:

Run up to her and ask her to join you at a chocolate shop?

or,

Hide and wait until the coast is clear to sneak into her room while she is gone?

Asking the player if he or she would rather talk to Celia or sneak into her room translates the poem's opening action into a decision that weighs values and desires, questions motives, and reveals attitudes about women, power, and privacy.

Unlike the usual reading experience of passively following Strephon's movements in the poem, the act of clicking a button to enter the dressing room oneself requires 
the player to self-consciously choose to intrude, raising awareness of the transgression of invading the privacy of another. Further, this other is no longer merely a referent exterior to the poem, but a someone from whom one decides to hide, whom one actively betrays, and whom one approaches in the spirit of determination rather than sociality. The act of choosing further invites a secondary, comparative reflection on Strephon going into the dressing room uninvited in the first place - why does he feel entitled to do so and what does he hope to discover? while the recognition of an alternative, to talk to Celia directly, proposes a reality in which Celia speaks and has authority and agency.

Those familiar with the poem need not be reminded that it is physically and sensuously dominated by material objects, presented in order of their increasing repugnance to Strephon. Their particularity and signifying possibility, however, are liable to narrow and fade with readerly progress. Objects may be only lightly touched by the eyes of readers swept up in the momentum of the poem's verse structure as metrical couplets encourage readers to accelerate their reading to complete the rhyme. Once having reached a place of sonorous and visual completion, the reader can move, satisfied, to the next line without further care for the details of what went on before. The result is that objects aren't slowly considered or weighed by readers but absorbed by the matrix of Strephon's visceral race to misogyny. By contrast, The Dressing Room stages isolated object encounters that playfully disembed these elements from the poem's authorized discourse by requiring the player to pause. He or she must make decisions, and, in doing so, unmask the presumption of authoritative objectivity in the poem as merely a troubled, subjective narrative.

From the carelessly cast-aside smock to the carefully concealed contents of the cabinet, every object-encounter in the game requires the player to enter into a complex psychological conversation that draws together a variety of identities and influences: their everyday embodied selves, their imagined self-image, the freedom they feel in a consequence-free virtual space, the words of the poem's speaker, and the actions and outcomes of its protagonist. A productive tension arises between the protagonist's diegetic, the satirical speaker's extra-diegetic, and the player's meta-diegetic narrative levels as the player's story unfolds. Unlike the audience Mulvey describes for film, the player can look freely around and is neither trapped nor passively complicit in the male gaze. Instead, the player is continually weighing the male gaze of the poem against other possibilities. The concurrent consciousness of the translation of poem-detail into narrative-decision replicates and emphasizes the interpretive act implicit in poetry-reading - of choosing the significance or meaning of words and images - as well as the consequences of those choices for the narrative of the poem the reader writes as he or she reads. After all, what is 
Strephon if not an interpreter-however inept - of cultural artifacts? What is the speaker if not an interpreter-however biased - of actions? The diegetical layering of the game parodies the various levels of the male-gaze by allowing interrogation of the assumptions of that gaze through independent movement as the player compares his or her interpretations with the deductions and dogmatism of Strephon and the speaker. By slowing reading down through digital play and considering and creating meaning line by line, object by object, choice by choice, the player's textual experience shifts from discerning what the poem is about to what possibilities the elements of the poem evoke.

To help ensure ease of play that doesn't distract from player engagement, I developed The Dressing Room using Twine 2.0, a platform that enables point-andclick interaction, graphics, and external links. One clear benefit of this point-andclick interface (as opposed to traditional text-input) for players is that it negates the potential for input errors (typos or spelling). Such errors might otherwise slow down the progress of the game, as well as risk frustration for players when they have to guess or acclimate to the unnatural lexicon of acceptable commands, an obstacle that turns the focus away from the play at hand. A further benefit lies in the ability to script informative and entertaining options for the player, and to make the language and tone of scene descriptions consonant with the selected user input, thereby maintaining the experiential consistency of the game's fictional world.

Functional, aesthetic, and interactive consistency is critical to the quality of absorption in the user experience. To develop designer sensitivity, game theorist Roger S. G. Sorolla has compiled a list of "crimes against mimesis" (1) that jeopardize the integrity of interactive-fiction worlds, including "contexts out of context," "genre bending," and breaking of fictional unity (5). The game design of The Dressing Room needed to maintain coherence to maintain unit: screen transitions needed to be logical, and the fictional world needed to remain faithful to Swift's poetic vision in both objects and tone. Creating a virtual world as a complementary extension and imitation of the poem's fictional and satirical world poses the challenge of crafting alternative outcomes for a poem that, among other things, dramatizes the hubris of unreflecting dogmatism in an associationist paradigm, particularly where sexism is concerned. A second challenge stems from considering how to generate and deploy the satirical energy of the poem across the game's multiple narrative outcomes. Both concerns were addressed by creating alternative narrative paths that embraced a comic irony in line with the poem's satire while also making them the product of subtly, and sometimes not so subtly differentiated ideological dispositions. The repeated embedding of comic irony in plotting and prose also, in theory, can refract the satiric glass to display a wide range 
of satiric possibilities, making player-exposure to satiric technique a mimetic and structural principle as well as a pedagogical and provocative one.

The game is composed of thirty-two different screens and seventeen different possible outcomes, with an average play-time of roughly four minutes per session. The majority of screens represent an encounter with a single object in the dressing room. The central feminist hypothesis of the game's architecture is that multiple encounters with these objects place interpretative possibility and subjective liberty at the center of the experience. After each move to a new screen, the player has the option to advance or return to the previous screen, and all links open to new, separate browser windows. When the player comes to the end of the game, there is the option to play again, as well as an opportunity to leave feedback via email about the experience (see figure 4).

Celia isn't perfect: she's messy. What a delight.
As Herrick says in his Definition of Beauty:
Beauty no other thing is, than a beam
Flash'd out between the middle and extreme.
To be perfect would be extreme.
She is now more beautiful to you than ever and you leave the dressing room a happy,
love-besotted Strephon, and seek out your Celia with a more sophisticated vigour.
Play Again
Tell us what you think!

\section{Figure 4: Typical final screen.}

The short duration of play is meant to encourage repeated play that keeps players in the dressing room world for an extended period. As a result, they can develop familiarity with objects Swift places in his poem and narrative progression in the poem while they also experiment with a variety of other outcomes for critical, comparative purposes. In traditional games of interactive fiction, the player succeeds by solving puzzles and ultimately achieving an established goal. Both Montfort and Sorolla have insisted that to be considered a "game" and not merely a space, interactive fiction must be goal-oriented in a terminal way. Montfort has gone so far as to promote "winnability" to an aesthetic principle, suggesting that interactive fiction games are "literary" within the narrow conception of the literary, poetic figurative language used in riddles and that winning such games is 
commensurate with riddle-solving-or more simply, developing the right interpretation (Montfort Twisty Little Passages 3-5, 13-15). ${ }^{12}$ Interactive fiction game design, he argues, relies on the solving of word puzzles or riddles (as opposed to a more kinetic game type that emphasizes agility of movement over agility of mind), requiring the same kind of attention to rules and representation as the language which structures a riddle. This approach, however, limits the literary interpretive horizon to a selection of the right meaning from the multiple signifying possibilities of language. Riddles may be poetic - and indeed, the riddle genre flourished in the Augustan period-but a poem, like a person, is not a riddle to be solved and its language, like one's appearance, belongings, or dressing room, is not a code to be broken.

One of the central design goals of The Dressing Room is to move students away from a practice of reading poetry that looks for a single solution to what it is about, concretizes the variables of a boiler-plate satiric equation, or upholds a pathology of the male-gaze in which there is but one way to look. "Winning" in The Dressing Room is therefore correlated with the individual player's increasing sensitivity to interpretive stakes of each poetic element. Inherent in this receptivity is recognition of the loss that occurs in the reification of subjective meaning-the unreflecting progression of reaction to interpretation to fact-particularly, in this poem's case, when the troubled relationship between knowledge and women permeates the narrative. As Cassel has argued, feminist game design embraces the goal of distributing authority over experience and recognizing the multiplicity of possibilities for interpretations of experience: "Rather than insisting on one right answer-one path through the software, for example-feminist software design conceives of users as diverse, and their paths through technology as equally diverse" (305). In sympathy with this approach, The Dressing Room offers a diversity of paths for players to follow and ways of seeing without anyone being "right."

\section{Classroom discussion and student reactions}

The Dressing Room is not meant as a standalone experience for students: it a springboard for class discussion, response paper reflection, and further poetic engagement. The gameplay is sufficiently short that a fraction of a class period can be devoted to it with time for discussion-or it can be an independent activity referenced in the following class. After playing the game a few times, students can come away prepared to join Swift in wrestling with difficult questions raised by the poem that are both historical and transhistorical, and to connect them to their own moment, thereby extending their participation as partial subject and object of the satiric gaze. In my course "Introduction to Humanities Literature," a general 
education course for non-majors, I asked students to play the game at home after reading the poem in preparation for class discussion. This allowed me to discuss the intellectual context and forces of the poem by expanding on the narrative choices within the game that elaborate on the relationship between, on the one hand, gender, power, and victimization, and, on the other, knowledge, the desire to know, and the limits we can surpass to gain information. The game-based conversation helped students to draw from their gameplay in order to make independent connections between poetic depictions of women as things or as constructions of things, such as in the poetry of Spencer and Herrick, and early science writings that use what Carolyn Merchant describes as metaphors of "domination and mastery of nature" that "either eliminated or used female principles in an exploitative manner," such as The Advancement of Learning (2). ${ }^{13}$

The conversation began with questions like the following: Who decided to go into the dressing room? Why did you go in? Did you feel entitled to do so? Because the game invites such entry by supplying players with the choice and, therefore, could be deemed ethical entrapment, I further ask: Would you do this in real life? Why or why not? Why is doing it in a game different? Why do you think Strephon went in? And, in a further vein of speculation, I ask them to draw from the text to tell me why they feel Strephon believes it is permissible for him to go into Celia's room and look around. Some students suggested that it is natural for us to want to find out more about the people we're attracted to but that he certainly crossed a line. Others thought that rummaging through Celia's chest was no different than rummaging through someone's Twitter, Facebook, or email accounts, in order, as one group put it (in free and fanciful scatological sympathy) "to find their shit out [in order] to have shit on them." Yet, as they comically posited, the poem shows that by "trying to get shit on others, we just get shit on ourselves," an irony of collapsed figurative and literal meaning not the least foreign to the Swiftian aesthetic.

The ensuing discussion focused on exploring the adjacent and conflicting models of privacy and transparency suggested by the poem and gameplaying experiences. When asked about the role of privacy in the poem, students identified two specular violations of privacy in the poem, Celia's and Strephon's. They understood this as ironic because, while he is looking through all of her private things without her knowing, we watch him via the speaker without his knowing. At the same time, students recognized how playing the game and entering into the role of Strephon offers the anonymity of the digital. The space of private online game-playing extends the imaginative and the sympathetic by being in someone else's shoes. At the same time, it invites a feeling of anonymous liberty, of being able to look without being seen that permeates digital spaces and enable behaviors like viewing 
online pornography, anonymous commenting, or any behavior, desire, or feeling that we are unwilling to expose to the public. Students, in turn, linked this feeling of anonymous license to the explosion of online misogyny via forums such as Twitter or Reddit. Exemplified in Strephon's presumption of private exploration, online privacy allows one to say, do, and search for whatever one desires without paying the price of exposure. On the other hand, students identified exposure as a central theme of the poem and one that is always adjacent to their online consciousness. How safe are they from observation, from the gaze of others when they think they are most secure? This question caused obvious discomfort yet led to one student productively making the connections between private selves and public selves. He established structural parallels of behavior modification between what he does online and how he acts in public social life and how Strephon behaves outside and inside the dressing room (a difference he acknowledged is implicit in the poem because Strephon sneaks into the dressing room and therefore doesn't want to be known as someone who sneaks into ladies' dressing rooms). He extended the parallel to connect with the distinction between the public Celia who lives outside the dressing room and the Celia who claims it as a space of privacy where she doesn't have to be whatever society says she should. This led another student to think of the dressing room as an "ironic double-mirror" because it exposes Celia's "physical truth" but also Strephon's “inner truth."

The introduction of "truth" as a conceit sparked discussion about whether the poem supports the idea that one could determine the truth or whether all "knowledge" is the product of interpretive bias. I asked students if they thought Strephon's conclusions were sound, and if playing with the objects in the game had changed their opinions since their first reading of the poem. Many students said they were surprised and laughed a lot at the other choices they could make, especially the ones that troubled received notions of masculinity, such as indulging in foppery by using Celia's comb to do their hair or taking the queering opportunity to try on her petticoats. One student was particularly enthusiastic about an outcome in which Celia's sisters were responsible for the mess, because this possibility demonstrated how widely the potential for interpretation could range from Strephon's.

The comical interpretations of objects and scenes made possible by alternative narrative possibilities displace and denaturalize Strephon's choices and deductions. When asked what they thought the poem satirized, almost all agreed that Strephon - not Celia - was the target. Some produced more complex responses that expanded the satiric gaze to interpretation itself. One student noted that, while Strephon was the target, Celia still gets made fun of, what she called the "sorry not sorry" or "I'm not saying but I'm just saying" version of satire. In other words, Swift is still making fun of women while he is making fun of Strephon for making 
fun of women. This astute comment sparked a brief discussion of parody as such and a difficult rhetorical challenge: how to ridicule what is distasteful to us without seeming distasteful ourselves. This opened a further discussion of the complexity of both satire and parody, as well as the necessity of distinguishing between the poet, the speaker, and the protagonist. When turning to the effect of satire on the reader, however, students shared feelings of embarrassment by extending the poem to real life in two ways, admitting that: (1) they too became obsessed with people and invaded their privacy in ways that rendered them "thing-like" and (2) they sometimes made what one student noted were hasty deductions and generalizations, which others could see as the first step toward misogyny, sexism, and other dangerous, dehumanizing ways of thinking.

While the discussion in my general education course was highly successful in terms of engagement and analytical inquiry, I was unable to gauge how much each student profited from playing the game itself. In a first-year course for English majors, "British Literature 1660-1900," in the following semester, I added a question to online response journals about students' experiences with the game and how it affected their relationship with and understanding of the poem. The majority of responses fell into one (or more) of four categories: (1) The game helped them to realize how intrusive and dehumanizing Strephon's actions were and that they themselves felt somewhat uncomfortable rooting through her things, and they enjoyed the game more when they were actually more comfortable talking to Celia rather than speculating about her in her absentia; (2) They enjoyed the multiple perspectives that were offered for each object and believed that being able to make choices to look at things or not, and about what to conclude about them, was both freeing and revelatory of just how narrow and bizarre Strephon's train of thought appeared by comparison; (3) The poem made them think about the objects more intensively, with some saying (as in the case of puppy water) that they were really interested in all the strange cosmetics of the eighteenth-century toilette and the differences between male and female hygiene expectations; (4) The interactions with Celia offered in a series of game paths and an outcome that lands Strephon in a Molly house stimulated desire to know more about eighteenth-century sexuality, gender, and courtship. It was gratifying to see that their reactions tended toward curiosities about the relationships of gender, sexuality, knowledge, and privacy. Taking advantage of their curiosity, I organized the next class discussion to examine how the poem engages, critiques, and satirizes those relationships. I also challenged students to consider how we can be both complicit and resistant readers on the diegetic and extradiegetic levels of the poem by reading it through the lens of feminist concerns with subjectivity and multiplicity. In a more advanced class, I would think it advisable to pair a range of feminist readings of the poem with the game to give further direction and shared vocabulary to the discussion; however, 
this high level of reading would have been prohibitively difficult for my two student groups, and I was pleased to see them enter into the paradigm of feminist inquiry in their readings and critiques of the poem through their own playful experience.

\section{Complementary collaborative assignment}

Using the interactive fiction framework of the game proved to be a stimulating way to deconstruct Swift's poem into a series of decisions around objects and actions that slowed down reading and helped students engage more playfully and critically with the poem. Building on this experience in an attempt to move students further from the passive to the active, I developed an assignment that would ask them to apply this approach collaboratively to other course texts. In self-selected groups, the students were responsible for taking a critical moment from a future course text and supplying alternatives to what the protagonist or speaker does. To do so successfully, they needed to (1) Place the player in the role of a protagonist or (lyric) speaker; (2) Give two original choices; (3) Demonstrate research about the period; (4) Make a literary connection; (5) Attempt to do so in a playful, satirical way. Students then had to present their choices and outcomes to the class and elaborate their thinking for each decision in a digital format. The learning level, size, and scope of these two courses made requiring the use of Twine for the assignment prohibitive, though, under other conditions, asking students to design their own Twine games would be appropriate. Some of my more advanced students did learn Twine to create a game experience; others, however, relied on PowerPoint and Google Slides with internal links, ultimately achieving a similar user interface. Regardless of the technology they employed, students exercised subjective freedom in their poetic exploration while working collaboratively to reciprocally create opportunities for further learning and discussion in the classroom.

Below is a particularly successful example taken from one series of choices in a game crafted by an eager and talented group of students that was based on Alexander Pope's The Rape of the Lock: 
You stand behind Belinda, seated, not knowing you are there. On a table near-by you see scissors, a plate of cookies, and a fan:

Do you:

1. Cut off a lock of her hair

2. Take a cookie and walk around the room to see what else is there

3. Take the fan thinking it is Belinda's

\section{Result, Option 1.}

You take the scissors and snap off a bouncy curl.

You are freak.

You are a sick freak.

I hope she grabs those scissors and stabs you...Title IX! Title IX! . .

\section{Result, Option 2.}

The cookie is crisp and buttery with a subtle flavor new to your jaded palate. Your interest peaks! This is more than a mere aphrodisiac: this is the main event: "I dare say, what's in these biscuits...they're very nice... Vanilla! Vanilla you say? Queen Elizabeth you say? Hugh Moran you say? Investment opportunity in flora transplantation you say? Colonialism you say...? HUGE profits you say? Sign me up... Remarkable!

\section{Result, Option 3.}

You take the fan, only to discover as you unfold that a riddle is contained inside:

Because I am by nature blind, I wisely choose to walk behind;

However, to avoid disgrace, I let no creature see my face. My words are few, but spoke with sense;

And yet my speaking gives offence:

Or, if to whisper I presume, The company will fly the room.

By all the world I am opprest:

And my oppression gives them rest.

As you stand there, the French beans and venison you ate earlier start to rumble in your stomach. You decide to keep the fan for more practical reasons. 
This remarkable student work was not only funny - the whole class was laughing but also showed further research into Pope's writing, as well as research into the history of cookies and cookie-making in Britain with which I was unfamiliar. Though the research was not intensive, it was focused and clever and made connections with the poem in surprising ways. I also appreciated that the group, which was composed of young women, continued to employ approaches of feminist critique from our prior discussions of Swift. In the future, I will likely add an independent writing component for group members so that they can each express and reflect on the effect of an interactive fiction approach on their reading.

The most exciting result of using The Dressing Room and its complementary assignment from a feminist pedagogical standpoint was that students were able to draw from their gameplaying experience to independently craft approaches to a challenging poem, The Rape of the Lock, that helped them to engage productively with it. Moreover, they were able to do so with amusement while working collaboratively to inspire continued feminist reading for the rest of the class. Mediated by feminist principles of subjectivity, distributed authority, experience, and multiplicity, students absorbed the counterfactual methodology of interactive fiction as a portable skillset that changed their relationship to poetry. It enabled them to explore poetry not as a scavenger hunt for meaning but as a space of objects, ideas, and decisions where they could actively inquire into multiple motives, meanings, and relationships. They developed agency as readers, viewing poetry as a space of play and possibility rather than as riddles to be solved. It is somewhat ironic, then, that the digital space that relies on coding to produce its effects proved so useful in moving students away from the decoding approach to poetic reading. A further irony unfolds in considering that digital gameplay, with its dark legacy of Gamergate and sexist constructions of women, could introduce feminist methodologies so effectively to their players. It is my hope that this pedagogical gaming experiment illustrates how both the digital world of gameplay and the playfulness of Augustan poetry can be reclaimed and reinvigorated by feminist methodologies in such a way that all our student readers are able to play to "win."

Entering the Lady's Dressing Room is currently undergoing a Beta revision. The current version can be found at www.eigtheenthcenturygames.tumblr.com. The author welcomes any commentary or critique from those who would like to use it in their classrooms or play it on their own.

\section{NOTES}

\footnotetext{
${ }^{1}$ The principles of feminist pedagogy can be outlined in a variety of ways but tend to cluster around these terms as defined by Justine Cassel. A common alternative expression of similar ideas
} 
outlines feminist pedagogy as participatory learning, validation of personal experience, encouragement of social understanding and activism, and development of critical thinking and open-mindedness; however, the emphasis on activism common to women's and gender studies applications of these principles is not strongly emphasized in this exercise. Frances L. Hoffman and Jayne E. Stake have argued that feminist pedagogy "should . . encourage the translation of these feminist principles in the service of social justice. Feminist scholars and teachers are interested in understanding the nature of gender inequality in order to redress it" (81-82). In both the digital game and the attendant assignment, activism does not necessarily extend beyond developing strong close-reading skills that enable students to question received narratives, imagine alternatives, and develop, in some cases, parodic skills to neutralize sexist common places and the ubiquity of the male gaze.

${ }^{2}$ The questions of misogyny in the poem and of the poet Swift have a history as long as the poem itself, with contemporary readers and modern critics alike unable to agree on whether the poem satirizes misogynistic thinking or is complicit in such thought or if this is the personal position of the author himself. Major contributors to these questions include but are not limited to Louise K. Barnett, Margaret Ann Doody, "Swift Among the Women," Susan Gubar, Carol Houlihan Flynn, Nora Crow Jaffe, and Ellen Pollak, The Poetics of Sexual Myth.

${ }^{3}$ As Chico writes, Strephon "is obsessed with the production of experimental knowledge," but his "error" is "methodological" (146).

${ }^{4}$ See, for example, Laura Brown's argument: "Through a kind of metonymy, the products of mercantile capitalism with which women surround and adorn themselves come to be implicated with the female body itself" (180).

${ }^{5}$ The Dressing Room reproduces the following items from "The Lady's Dressing Room": allum flower, brush, cap, Celia's excrement, the chest, comb, dandruff, filthy basin, handkerchief covered in snuff and snot, hair, lead, leather-gloves, magnifying mirror, oily cloth, powder, puppy water, smock, stockings, towels dirtied with sweat and ear-wax, various pots of cosmetics, worm. ${ }^{6}$ The seventeen game outcomes include the following: (1) White's Chocolate House with Celia; (2) White's Chocolate House with Celia and roses; (3) Chocolate with Celia in her salon; (4) Take a trip to the apothecary; (5) Renewed love of Celia because of her imperfection; (6) Feel foolish and leave; (7) Develop a new-found sense of moral-certainty; (8) Take your fashionable hair out on the town; (9) Leave disgusted at Celia; (10) Leave disgusted with all woman-kind; (11) End up in Bedlam; (12) Go Tom's on Great Russel Street to buy snuff; (13) Take a bath at home; (14) Seek your destiny in a Molly House; (15) Establish your new career as the skin-care guru of London; (16) Go home to contemplate Milton's poetic genius; (17) Exit the Dressing Room a sadder and a wiser man, and perhaps buy a new wig.

${ }^{7}$ See Horace, 1.10.37.

${ }^{8}$ For the original quotation, see Swift, Journal36.

${ }^{9}$ See Ingram 40-81.

${ }^{10}$ These games included Below the Root (1984), Swiss Family Robinson (1984), The Wizard of Oz (1985), Alice in Wonderland (1985), and Treasure Island (1985).

${ }^{11}$ See, for example, the sophisticated MPG, Ever, Jane (2016) and Jane Austen: Dress Up. What Jane Saw (2013) virtually reconstitutes art exhibitions that Jane Austen visited.

${ }^{12}$ See also chapter 2 in Montfort, Twisty Little Passages.

${ }^{13}$ Works cited in Entering the Lady's Dressing Room include the following: Francis Bacon, The Advancement of Learning (1605); Daniel Defoe, The Adventures of Robinson Crusoe (1719); John Dryden, Aureng-Zebe (1675); Robert Herrick, "Definition of Beauty" (1648) "To the Virgins, to Make Much of Time" (1648) and "Delight in Disorder" (1648); John Locke, An Essay Concerning Human Understanding (1689); John Milton, Paradise Lost (1667) and Samson Agonistes (1671); Michel de Montaigne, "Of Smells" (1580); Samuel Pepys, Diary of Samuel Pepys, Sunday, 8 April 1666; William Shakespeare, The Tragedy of King Lear (1606); Edmund 
ABO: Interactive Journal for Women in the Arts, 1640-1830, Vol. 10 [2020], Iss. 1, Art. 2

Spenser, Sonnet 64, “Amoretti” (1595); Jonathan Swift, Directions to Servants (1745), Gulliver's Travels (1726), "Verses on the Death of Dr. Swift" (1739), and "Strephon and Chloe" (1734); Richard Steele, The Tatler, No. 15 (1709). 


\section{Works Cited}

Alderson, Simon J. "The Augustan Attack on the Pun." Eigtheenth-Century Life, vol. 20, no. 3, 1996, pp. 1-19.

Barnett, Louise K. Jonathan Swift in the Company of Women. Oxford UP, 2006.

Bloom, Gina. "Videogame Shakespeare: Enskilling Audiences through TheaterMaking Games." Shakespeare Studies vol. 43, 2015, pp. 114-27.

Bogel, Frederic V. "The Difference Satire Makes: Reading Swift's Poems." Theorizing Satire: Essays in Literary Criticism, edited by Brian A. Connery and Kirk Combe, Palgrae Macmillan, 1995, pp. 43-53.

Brower, Reuben. "Reading in Slow Motion." In Defense of Reading: A Reader's Approach to Literary Criticism, edited by Reuben Brower and Richard Poirier, E. P. Dutton, 1962, pp. 3-21.

Brown, Laura. Ends of Empire: Women and Ideology in Early Eighteenth-century English Literature. Cornell UP, 1993.

Brown, Laurene Krasny. Taking Advantage of Media: A Manual for Parents and Teachers. Routledge, 1986.

Cassell, Justine. "Storytelling As a Nexus of Change in the Relationship Between Gender and Technology: A Feminist Approach to Software Design." From Barbie to Mortal Kombat: Gender and Computer Games, edited by Justine Cassell and Henry Jenkins, MIT P, 1998, pp. 298-326.

Chico, Tita. Designing Women: The Dressing Room in Eighteenth-Century English Literature and Culture. Bucknell UP, 2005.

Doody, Margaret Anne. The Daring Muse: Augustan Poetry Reconsidered. Cambridge UP, 1985.

—. "Swift Among the Women." Critical Essays on Jonathan Swift, edited by Frank Palmeri, G. K. Hall, 1993, pp. 13-37.

Flynn, Carol Houlihan. The Body in Swift and Defoe. Cambridge UP, 1990. 
Gamman, Lorraine. "Watching the Detectives: The Enigma of the Female Gaze." The Female Gaze: Women As Viewers of Popular Culture, edited by Lorraine Gamman and Margaret Mashment, Real Comet P, 1988, pp. 8-21.

Gee, James Paul. What Video Games Have to Teach Us About Learning and Literacy. Palgrave Macmillan, 2003.

Gubar, Susan. “The Female Monster in Augustan Satire.” Signs, vol. 3, 1977, pp. 380-94.

Hoffmann, Frances L., and Jayne E. Stake. "Feminist Pedagogy in Theory and Practice: An Empirical Investigation.” NWSA Journal, vol. 10, no.1, 1998, pp. 79-97.

Holm, Melanie. Entering the Lady's Dressing Room: An Online Text Adventure. Tumblr, 12 Apr. 2018, https://eighteenthcenturygames.tumblr.com/. Accessed 7 Feb. 2020.

Horace. Horace: Satires, Book 1, edited by Emily Gowers. Cambridge UP, 2012.

Ingram, Allan. Intricate Laughter in the Satire of Swift and Pope. Macmillan, 1986.

Jaffe, Nora Crow. The Poet Swift. UP of New England, 1977.

Mahon, Derek. “On Swift's Poetry." The Essential Writings of Jonathan Swift, edited by Claude Rawson and Ian Higgins, Norton, 2010, pp. 795-802.

Merchant, Carolyn. The Death of Nature: Women, Ecology, and the Scientific Revolution. Harper, 1983.

Montfort, Nick. "Toward a Theory of Interactive Fiction." IF Theory Reader, edited by Jackson Mead and J. Robinson Wheeler, Transcript On P, 2011, pp. 2558.

—. Twisty Little Passages: An Approach to Interactive Fiction. MIT P, 2003.

Mulvey, Laura. "Visual Pleasure and Narrative Cinema." Film Theory and Criticism: Introductory Readings, 5th ed., edited by Leo Braudy and Marshall Cohen, Oxford UP, 1999, pp. 833-44. 
Pollak, Ellen. The Poetics of Sexual Myth: Gender and Ideology in the Verses of Swift and Pope. U of Chicago P, 1985.

-. "Swift Among the Feminists: An Approach to Teaching." College Literature, vol. 19, no. 1, 1992, pp. 114-20.

Probyn, Clive T. "Swift's Early Odes: The Unreadable in Search of the Unspeakable." Reading Swift: Papers from the Fifth Münster Symposium on Jonathan Swift, edited by Hermann Josef Real, Wilhelm Fink Verlag, 2008, pp. 275-286.

Redmond, John. How to Write a Poem. Blackwell, 2006.

Sorolla, Roger S. G. "Crimes Against Mimesis." IF Theory Reader, edited by Jackson Mead and J. Robinson Wheeler, Transcript On P, 2011, pp. 1-24.

Swift, Jonathan. A Tale of a Tub and Other Works. Edited by Marcus Walsh, Cambridge UP, 2010.

—. The Journal to Stella. Vol 1., edited by Harold Williams, Clarendon, 1948. 2 vols.

—. "The Lady's Dressing Room." The Poems of Jonathan Swift. Vol. 2, edited by Harold Williams, Clarendon, 1958, pp. 143-44.

ZORK I: The Great Underground Empire: Infocom Interaction Fiction-A Fantasy Story. Infocom, 1981. 